\title{
Thymidine Metabolism in Mycoplasma hominis
}

\author{
By D. A. STOCK AND G. A. GENTRY* \\ Department of Microbiology, University of Mississippi School of Medicine, \\ Jackson, Mississippi 39216, U.S.A.
}

(Accepted for publication 2 December 1970)

Production of extracellular deoxyribonuclease (Randall, Gafford, Gentry \& Lawson, 1965) by Mycoplasma hominis suggested that this organism might use a scavenger pathway (Fig. I) to supply thymidine (TdR) nucleotides for deoxyribonucleic acid synthesis as has been suggested for $M$. laidlawii (Razin, 1962; Smith, 1964). To determine if this was a reasonable possibility we assayed in fractions of $M$. hominis the activity of several enzymes involved in the synthesis of thymidylate (dTMP) and its incorporation into DNA (as the triphosphate).

The methods used to grow, harvest and fractionate the organisms have been described (Stock \& Gentry, 1969). Briefly, washed cell pellets were lysed by osmotic shock and freezing and thawing, and then centrifuged. The supernatant was used as the cell-free extract.

Thymidine (TdR) kinase (EC 2.7.I.2I) was assayed essentially as described by Takahashi, Ueda \& Ogino (1966). The aqueous reaction mixture contained $22 \cdot 7 \mu$ moles $\mathrm{KCl}, 2.5 \mu$ moles ATP, $3 \mu$ moles 3-phosphoglycerate, $2.5 \mu$ moles $\mathrm{MgCl}_{2}$, $\mathrm{I} \cdot 5 \mu$ moles trishydroxymethylaminomethane (tris), $\mathrm{pH} 7 \cdot 8, \mathrm{I} 6 \cdot 7 \mu$ moles $\operatorname{TdR}\left[2-{ }^{14} \mathrm{C}\right]$ $(5 \mathrm{nCi})$, and $0.1 \mathrm{ml}$. enzyme preparation, all in $0.5 \mathrm{ml}$. final volume.

DNA nucleotidyl transferase (EC 2.7.7.7) was assayed by the method of Magee (1962). The reaction mixture contained Io $\mu \mathrm{g}$. highly polymerized, heat-denatured L-cell DNA as primer; 75 nmoles each of the triphosphates of TdR, deoxyadenosine, and deoxyguanosine; $\mathrm{I} \cdot 3$ nmoles $\left[{ }^{3} \mathrm{H}\right]$ deoxycytidine triphosphate (dCTP) $(2 \cdot 5 \mu \mathrm{Ci})$; $0.5 \mu$ moles 2-mercaptoethanol; I $5 \mu$ moles tris, $\mathrm{pH} 7.8 ; 2.5 \mu$ moles $\mathrm{MgCl}_{2}$; and $0 . \mathrm{I} \mathrm{ml}$. enzyme preparation in $0.5 \mathrm{ml}$. final volume.

Deoxycytidylate (dCMP) deaminase (EC 3.5.4 . I2), was assayed with the following reaction mixture: $2.5 \mu$ moles tris, $\mathrm{pH} 7.4 ; 32$ nmoles $\left[2{ }^{14} \mathrm{C}\right] \mathrm{dCMP}$ ( $2.5 \mathrm{nCi}$ ); and $0.1 \mathrm{ml}$. enzyme preparation in $0.25 \mathrm{ml}$. final volume. The reaction was stopped by freezing at $-20^{\circ}$; after thawing, $50 \mu \mathrm{l}$. of the mixture was spotted on Whatman no.3 paper, which then was developed in a mixture of $75 \mathrm{ml} .95 \%$ ethanol $+30 \mathrm{ml}$. I Mammonium acetate, $\mathrm{pH} 7.5$ (Solvent system 29, Schwarz Bioresearch Catalogue 1966). The chromatogram was scanned (Vanguard Autoscanner) to locate the peak of $\left[2^{-14} \mathrm{C}\right]$ deoxyuridine monophosphate (dUMP). The peak was eluted with water and counted in a liquid scintillation spectrometer (Packard Instrument Co.).

dTMP synthetase (EC 2.I.I.b) was assayed by the method of Lomax \& Greenberg (1967). The reaction mixture contained $40 \mu$ moles tris, $\mathrm{pH} 7.4 ; 26 \mu$ moles $\mathrm{MgCl}_{2}$; I.06 $\mu$ moles ethylenediamine-tetraacetate; $106 \mu$ moles 2-mercaptoethanol; I $5.8 \mu$ moles

\footnotetext{
* Present address: Institute of Virology, Church Street, Glasgow.
} 
formaldehyde; $37.6 \mathrm{nmoles}$ tetrahydrofolic acid; 0.5 nmoles $\left[{ }^{3} \mathrm{H}\right] \mathrm{dUMP}(0.5 \mu \mathrm{Ci})$; and $0.1 \mathrm{ml}$. enzyme preparation in $\mathrm{I} .0 \mathrm{ml}$. final volume.

The method of Lowry, Rosebrough, Farr \& Randall (195I) was used for measurement of protein.

All incubations were for $30 \mathrm{~min}$. at $37^{\circ}$. The values found, each representing the average of assays of four separate cell-free extracts, were, in nmoles of product formed/ min./mg. protein, DNA nucleotidyl transferase, 0.002 nmole dCTP (made acidinsoluble); TdR kinase, I4.6 nmoles dTMP; dCMP deaminase, 5.4 nmoles dUMP; and dTMP synthetase, 0.093 nmole dTMP.

Excepting dTMP synthetase, considerable variation in enzyme activity was noted from sample to sample, but this may stem from the uneven distribution of activity between the soluble fraction and the membranes. The latter contained variable amounts of the several activities, although with few exceptions less than the corresponding cell-free extracts. The data do, however, indicate that Mycoplasma hominis has

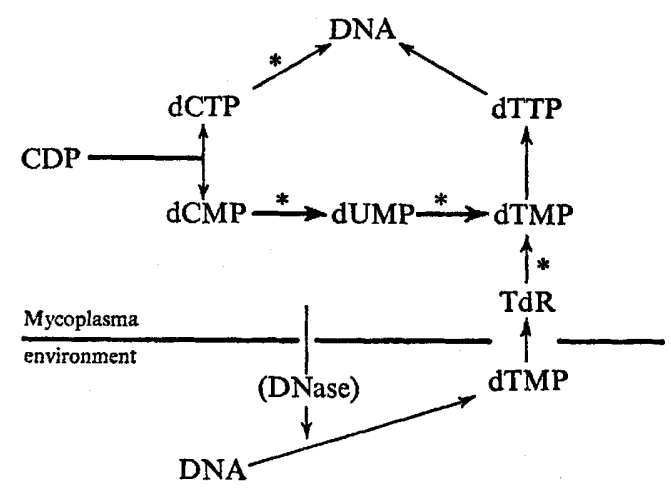

Fig. I. Suggested pathway of thymidine metabolism in Mycoplasma hominis. The de novo pathway to dTMP begins with dCMP; the scavenger pathway begins with DNA in the extracellular environment. Enzymes demonstrated in the present study are marked with an asterisk. Except for CDP, the nucleoside diphosphates have been omitted as well as the nucleosides other than TdR. TdR may also serve as a source of deoxyribose for the synthesis of other deoxyribonucleotides, by means of nucleoside phosphorylase (Razin \& Knight, I960).

the enzymes needed to provide the thymine moiety for DNA synthesis either via the de novo pathway from dCMP, or via the scavenger pathway from exogenous TdR. This is in apparent contrast to $M$. laidlawii B which shows an absolute growth requirement for exogenous $\mathrm{TdR}$ (Smith \& Hanawalt, I968), although in this case the inability to synthesize $\mathrm{TdR}$ de novo may reflect a defect in folate metabolism rather than the absence of dTMP synthetase. Which pathway $M$. hominis uses when both substrates are available is not presently known, although Gentry \& Stock (I969) have shown that, in L-cell cultures prelabelled with $\left[2{ }^{14} \mathrm{C}\right] \mathrm{TdR}$ and doubly infected with $M$. hominis and equine abortion virus, label could subsequently be demonstrated in the $M$. hominis DNA.

It is a pleasure to thank Barbara McMullen for her excellent technical assistance. This research was supported by USPHS grants AI 09858, AI 02032, 5- $\mathrm{K}_{3}$-AI $702 \mathrm{I}$ (G. A. G.), AI-69, and CA 805I (D. A. S.). 


\section{REFERENCES}

GeNTRY, G. A. \& Stock, D. A. (1969). Mycoplasma and Malignancy: a Nonspecific Aspect. In Proceedings of the International Symposium on Mycoplasma Diseases of Man, pp. 173-176. Jena: Fischer Verlag.

LomAX, M. I. S. \& GreenBerG, G. R. (I967). A new assay of thymidylate activity based on the release of tritium from deoxyuridylate-5-3 $\mathrm{H}$. Journal of Biological Chemistry 242, 109-1 13.

Lowry, O. H., Rosebrough, N. T., FARR, A. R. \& RANDALl, R. J. (I95I). Protein measurements with the Folin phenol reagent. Journal of Biological Chemistry $\mathbf{x 9 3}, 265-275$.

MAGEE, W. E. (1962). DNA polymerase and deoxyribonucleotide kinase activities in cells infected with vaccinia virus. Virology $17,604-607$.

RANDAll, C. C., GafFord, L. G., GeNTRY, G. A. \& Lawson, L. A. (1965). Lability of host-cell DNA in growing cell cultures due to Mycoplasma. Science, New York 149, 1098-1099.

RAZIN, S. (1962). Nucleic acid precursor requirements of Mycoplasma laidlawii. Journal of General Microbiology 28, 243-250.

RazIN, S. \& KNIGHT, B. C. J. G. (I960). The effects of ribonucleic acid and deoxyribonucleic acid on the growth of Mycoplasma. Journal of General Microbiology 22, 504-519.

Smith, D. W. \& Hanawalt, P. C. (I968). Macromolecular synthesis and thymineless death in Mycoplasma laidlawii в. Journal of Bacteriology 96, 2066-2076.

SMITH, P. F. (1964). Comparative physiology of pleuropneumonia-like and L-type organisms. Bacteriological Reviews 28, 97-125.

STOCK, D. A. \& GeNTRY, G. A. (1969). Mycoplasmal deoxyribonuclease activity in virus-infected L-cell cultures. Journal of General Virology 3, 313-3I7.

TAKAHASHI, M., UEDA, S. \& OGINO, T. (1966). Enhancement of the thymidine kinase activity of human embryonic kidney cells and newborn hamster kidney cells by infection with human adenovirus types 5 and 12. Virology 30, 742-743. 